\title{
PERFORMANCE EVALUATION OF LQ45 STOCKS IN THE INDONESIA STOCK EXCHANGE DURING PERIOD OF 2016-2018
}

\author{
Happy Catherine', Robiyanto Robiyanto ${ }^{2}$ \\ ${ }^{1,2}$ Faculty of Economics and Business, Universitas Kristen Satya Wacana, Salatiga, Indonesia \\ e-mails: ${ }^{1}$ happycatherine29@gmail.com; ${ }^{2}$ robiyanto.robiyanto@uksw.edu
}

Received June 5, 2020; accepted June 30, 2020; published July 1, 2020.

\begin{abstract}
Objective: This study investigates the performance evaluation of each LQ45 stock in the Indonesia Stock Exchange conducted by using the Sharpe Index, Treynor Ratio, Jensen Alpha, Sortino Ratio, and Information Ratio. Stocks evaluated are those that consistently listed in the LQ45 index during 2016-2018. Research Design \& Methods: The number of samples used in this study was 32 stocks taken using a purposive sampling technique. The data used in this study are the monthly closing price of stocks, the composite stock price index, and the BI 7-day Repo Rate interest rate data. Findings: The results of this study show that not all stocks included in the LQ45 index have good performances. The results of this study show that BBCA stock is the best stocks based on Sharpe Index and Information Ratio. Based on the Jensen Alpha method and the Sortino Ratio, PTBA stock is the best stocks. As for the Treynor Ratio method, the best stock is INCO. Recommendations: There is a blemish in research for further research that is expanding the scope of research, not only companies included in LQ45. Future studies can analyze portfolios consisting of LQ45 stocks and updating periods because stock performance is cyclical. Contribution \& Value Added: This research contributes to the analysis of LQ45 stock performance based on five methods including Sortino and Information Ratio that are rarely used and show differences in the results of the five stock performance indices.
\end{abstract}

Keywords: information ratio; Jensen Alpha; Sharpe Index; Sortino Ratio; Treynor Ratio.

JEL codes: B26, D04, G14, L25

Article type: research paper

\section{INTRODUCTION}

In creating a stock portfolio, several indicators concern investors, namely the stock price index and more specifically the Composite Stock Price Index (CSPI) (Robiyanto, 2018). This stock price index helps investors to see changes in the price movements of a group of stocks that form an index with criteria set by the IDX. Therefore it can enable investors to see a decline or increase in their stock portfolio price. Based on the official IDX website (www.idx.co.id) accessed in May 2019, there are 22 types of stock price indexes on the IDX.

The index that is the main concern of investors in creating stock portfolios is the LQ45 index. Firms included in the index are companies that have the highest liquidity and biggest market capitalization and have good corporate fundamentals (Devaki, 2017). To be in the LQ45 index entry, a company must meet the existing criteria, because these investors are more interested in creating a portfolio of stocks that included in the LQ45 index (Wahyuningrum, 2010).

Companies listed in the LQ45 index are often included in investor stock portfolios (Nurhayati, Suryantini, \& Jamhari, 2017). According to Larasati, Irwanto, \& Permanasari (2013), the LQ45 index controls almost $70 \%$ of equity ownership in the capital market. The stocks included in the LQ45 index are liquid stocks, these stock trading transactions are high according to the frequency and volume of 
stock trading, and have good growth prospects and financial conditions in the long-time, do not fluctuate and have been objectively selected based on predetermined criteria (Chandra \& Hapsari, 2013). Those are why investors use the LQ45 index to create a portfolio.

To assess portfolio performance, there are many measurement instruments used, such as Sharpe index introduced by Sharpe (1966) and Treynor ratio introduced by Treynor (1965), Jensen index introduced by Jensen (1967), Adjusted Sharpe Index (ASI), Adjusted Jensen Alpha Index (AJI), Sortino Ratio and Information Ratio. Research conducted by Zakarias \& Tumewu (2015) using the Sharpe, Jensen, and Treynor indices to measure the portfolio performance of 11 stocks from 2008 to 2012 shows that there are no differences between the three indices, so investors can use these indexes to evaluate stock performance. Whereas in the study of Pangestuti, Wahyudi, \& Robiyanto (2017) using the Sharpe, Treynor, Jensen index, ASI index, AJI, and Sortino ratios to evaluate 42 mutual fund's performance, the results showed SAM Indonesian Equity was the best performing mutual fund during the study period. Flotyński (2015) measures stock efficiency with five methods and makes the most efficient index ranking of Sharpe Ratio, Jensen Alpha, Treynor Ratio, Information Ratio, and Sortino Ratio. Suryani \& Herianti (2015) in their research to measure the LQ45 stock portfolios performance in the period 2010-2014 using 3 methods namely Sharpe Ratio, Treynor Ratio, and Jensen Index and conclude that the company with the best performance is BBNI according to Sharpe Ratio, TINS according to Treynor Ratio, and BBRI according to Jensen Index.

Several earlier studies that measured portfolio performance focused more on three methods, namely Sharpe Index, Jensen Alpha, and Treynor Ratio. The use of the Sortino Ratio and Information Ratio has not been widely used to measure portfolio performance. Therefore, this study will use the Sharpe Index, Treynor Ratio, Jensen Alpha, Sortino Ratio, and Information Ratio to measure stock performance included in the LQ45 index in the period 2016-2018. This study aims to aid investors in determining the portfolio-forming stocks taken from the LQ45 index by calculating the best riskreturn. For academics, this study contributed to the literature on stock performance analysis, both for further research and in supporting teaching and learning activities.

\section{LITERATURE REVIEW}

\section{Sharpe Index}

The Sharpe Index was originally introduced by Sharpe (1966). This index takes into account the standard deviation of portfolio returns (Leković, 2017). According to Pangestuti et al. (2017), Sharpe Index is one method to compare the work of each portfolio or stocks with the concept used is the capital market line or commonly known as Reward to Variability (RVAR). This index measurement aims to evaluate portfolio performance and each stock with risks that cannot be diversified or diversifiable risk (Putra, Atahau, \& Robiyanto, 2018).

\section{Treynor Ratio}

Treynor Ratio introduced by Treynor (1965) also called the Reward to Volatility Ratio (RVOL) (Pangestuti et al., 2017). This ratio only measures systematic risk, in contrast to the Sharpe Index which uses total risk as a calculation (Leković, 2017). This ratio measures each portfolio performance or stock by comparing the level of return with the amount of systematic risk faced so that the higher the value of this ratio means the better portfolio performance of each stock (Leković, 2017). The assumption in calculating the Treynor Ratio is that the portfolio or each stock is well-diversified, and so uses beta as a systematic risk (Lakaba \& Robiyanto, 2018).

\section{Jensen Alpha}

Jensen (1967) introduced another instrument to measure portfolio performance called Jensen Alpha. The Jensen Alpha Index is a special measurement of the risk-adjusted return of each portfolio or stock and takes into account the systematic risks faced (Robiyanto, 2018). Jensen Alpha is an index that uses the Capital Asset Pricing Model (CAPM) calculation to assess each portfolio or stock performance (Zakarias \& Tumewu, 2015). According to Zulkafli, Ahmad, \& Eky Ermal (2017), Jensen Alpha is a

JMER, 2020, 01(1), 37-44 
measure used to estimate a constant return with a systematic risk for investment carried out.

\section{Sortino Ratio}

Sortino ratios focus on calculating risk gains as seen from the level of risk-free (Sortino \& Price, 1994). Rollinger \& Hoffman (2013) states that the Sortino Ratio is a modification of the Sharpe Ratio by measuring the downside risk deviation as a measure of risk replacing the standard deviation. This ratio calculation uses portfolio return and Minimum Acceptable Return (MAR) as a numerator and downside deviation as the denominator (Sortino \& Price, 1994). This ratio supports the assessment of Markowitz (1959) that only downside risk is appropriate for investors.

\section{Information Ratio}

Information Ratios also called appraisal ratios. Also, Information Ratio is often called other forms or variations of Sharpe Ratio (Kidd, 2011). Information Ratio measures portfolio performance against benchmarks that are proportional to the risk-free rate (Hsieh \& Hodnett, 2013). This ratio in the calculation uses the return of excess return (excess return) and compares it with the risk or standard deviation of excess return (Blatt, 2004).

\section{Theoretical Framework}

There are various methods used to evaluate stock performance, among which are often used are Sharpe, Treynor, and Jensen Alpha. However, in this study analyzing stock performance with five methods, namely Sharpe Index, Treynor Ratio, Jensen Alpha, Sortino Ratio, and Information Ratio. Stocks that are consistently included in the LQ45 index will analyze based on these five methods. At the end of the paper, you will see where well and poorly performing stocks.

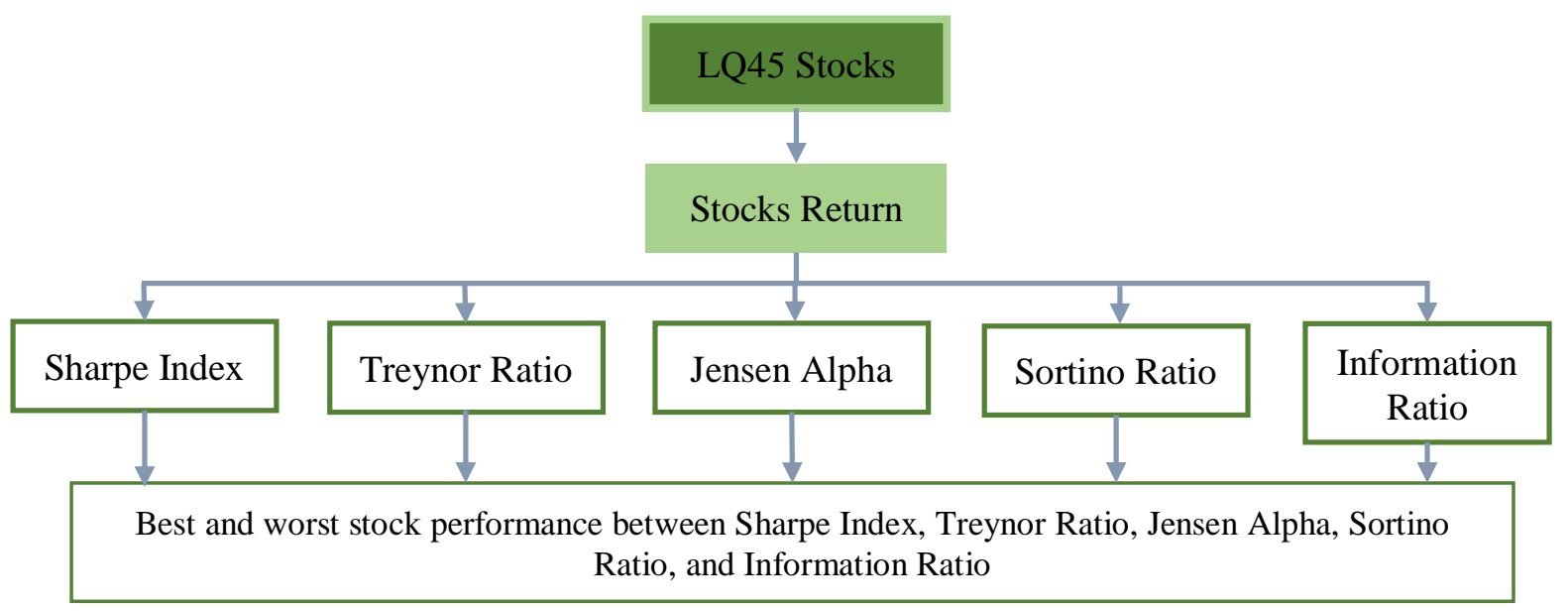

Figure 1. Theoretical Framework

\section{METHODS}

\section{Type and Data Source}

The population used in this study is the stock of companies included in the LQ45 index. Sampling in this study uses a purposive sampling method with criteria for stocks that are consistently included in the LQ45 index list during the 2016 - 2018 period. The list of stocks as shown in Table 1 below.

Table 1. List of LQ45 Stocks

\begin{tabular}{|c|c|c|}
\hline No. & Code of Company & Name of Company \\
\hline 1 & ADHI & Adhi Karya Tbk. \\
\hline 2 & ADRO & Adaro Energy Tbk. \\
\hline 3 & AKRA & AKR Corporindo Tbk \\
\hline
\end{tabular}




\begin{tabular}{|c|c|c|}
\hline No. & Code of Company & Name of Company \\
\hline 4 & ASII & Astra International Tbk. \\
\hline 5 & BBCA & Bank Central Asia Tbk. \\
\hline 6 & BBNI & Bank Negara Indonesia Tbk. \\
\hline 7 & BBRI & Bank Rakyat Indonesia Tbk. \\
\hline 8 & BBTN & Bank Tabungan Negara Tbk. \\
\hline 9 & BMRI & Bank Mandiri Tbk. \\
\hline 10 & BSDE & Bumi Serpong Damai Tbk. \\
\hline 11 & GGRM & Gudang Garam Tbk. \\
\hline 12 & ICBP & Indofood CBP Sukses Makmur Tbk. \\
\hline 13 & INCO & Vale Indonesia Tbk. \\
\hline 14 & INDF & Indofood Sukses Makmur Tbk. \\
\hline 15 & INTP & Indocement Tunggal Prakarsa Tbk. \\
\hline 16 & JSMR & Jasa Marga Tbk. \\
\hline 17 & KLBF & Kalbe Farma Tbk. \\
\hline 18 & LPKR & Lippo Karawaci Tbk. \\
\hline 19 & LPPF & Matahari Department Store Tbk. \\
\hline 20 & MNCN & Media Nusantara Citra Tbk \\
\hline 21 & PGAS & Perusahaan Gas Negara Tbk \\
\hline 22 & PTBA & Bukit Asam Tbk. \\
\hline 23 & PTPP & Pembangunan Perumahan Tbk. \\
\hline 24 & SCMA & Surya Citra Media Tbk. \\
\hline 25 & SMGR & Semen Indonesia Tbk. \\
\hline 26 & SRIL & Sri Rejeki Isman Tbk. \\
\hline 27 & SSMS & Sawit Sumbermas Sarana Tbk. \\
\hline 28 & TLKM & Telekomunikasi Indonesia Tbk. \\
\hline 29 & UNTR & United Tractors Tbk. \\
\hline 30 & UNVR & Unilever Indonesia Tbk. \\
\hline 31 & WIKA & Wijaya Karya Tbk. \\
\hline 32 & WSKT & Waskita Karya Tbk. \\
\hline
\end{tabular}

Sumber: Indonesia Stock Exchange (IDX) (2018)

\section{Operational Variables}

To avoid bias research indicators, the research model measure uses a formula under the earlier theory. Operational definitions of research variables seen in Table 2 below.

Table 2. Definition of Operational Variable

\begin{tabular}{|c|c|c|c|}
\hline No. & Variable & Definition & Measurement \\
\hline 1 & $\begin{array}{l}\text { Rate of return on } \\
\text { stock }\left(\mathrm{R}_{\mathrm{i}}\right)\end{array}$ & $\begin{array}{l}\text { Comparison of the difference } \\
\text { between the stock price of the } \\
\text { current period }\left(\mathrm{P}_{\mathrm{t}}\right) \text { and the stock } \\
\text { price of the previous year period }\left(\mathrm{P}_{\mathrm{t}}\right. \\
\text { 1) with the stock price of the } \\
\text { previous year period }\left(\mathrm{P}_{\mathrm{t}-1}\right) \\
\text { (Robiyanto, 2018). }\end{array}$ & $R_{i}=\frac{P_{t}-P_{t-1}}{P_{t-1}}$ \\
\hline 2 & Sharpe index $\left(S_{p}\right)$ & $\begin{array}{l}\text { Comparison of the difference } \\
\text { between stock returns }\left(R_{i}\right) \text { and risk- } \\
\text { free returns }\left(R_{\mathrm{f}}\right) \text { with total stock risk } \\
\left(\sigma_{\mathrm{i}}\right) \text {. The higher the Sharpe Index } \\
\text { value, the better the stock } \\
\text { performance (Zakarias \& Tumewu, } \\
2015) \text {. }\end{array}$ & $S_{p}=\frac{R_{i}-R_{f}}{\sigma_{i}}$ \\
\hline 3 & Treynor Ratio $\left(\mathrm{T}_{\mathrm{p}}\right)$ & $\begin{array}{l}\text { Comparison between the difference } \\
\text { in stock returns }\left(\mathrm{R}_{\mathrm{i}}\right) \text { and risk-free } \\
\text { returns }\left(\mathrm{R}_{\mathrm{f}}\right) \text { with beta }\left(\beta_{\mathrm{i}}\right) \text {. The beta } \\
\text { used is a systematic risk relative to } \\
\text { market risk. The higher the Treynor } \\
\text { ratio, the better the stock } \\
\text { performance (Lakaba \& Robivanto, }\end{array}$ & $T_{p}=\frac{R_{i}-R_{f}}{\beta_{i}}$ \\
\hline
\end{tabular}




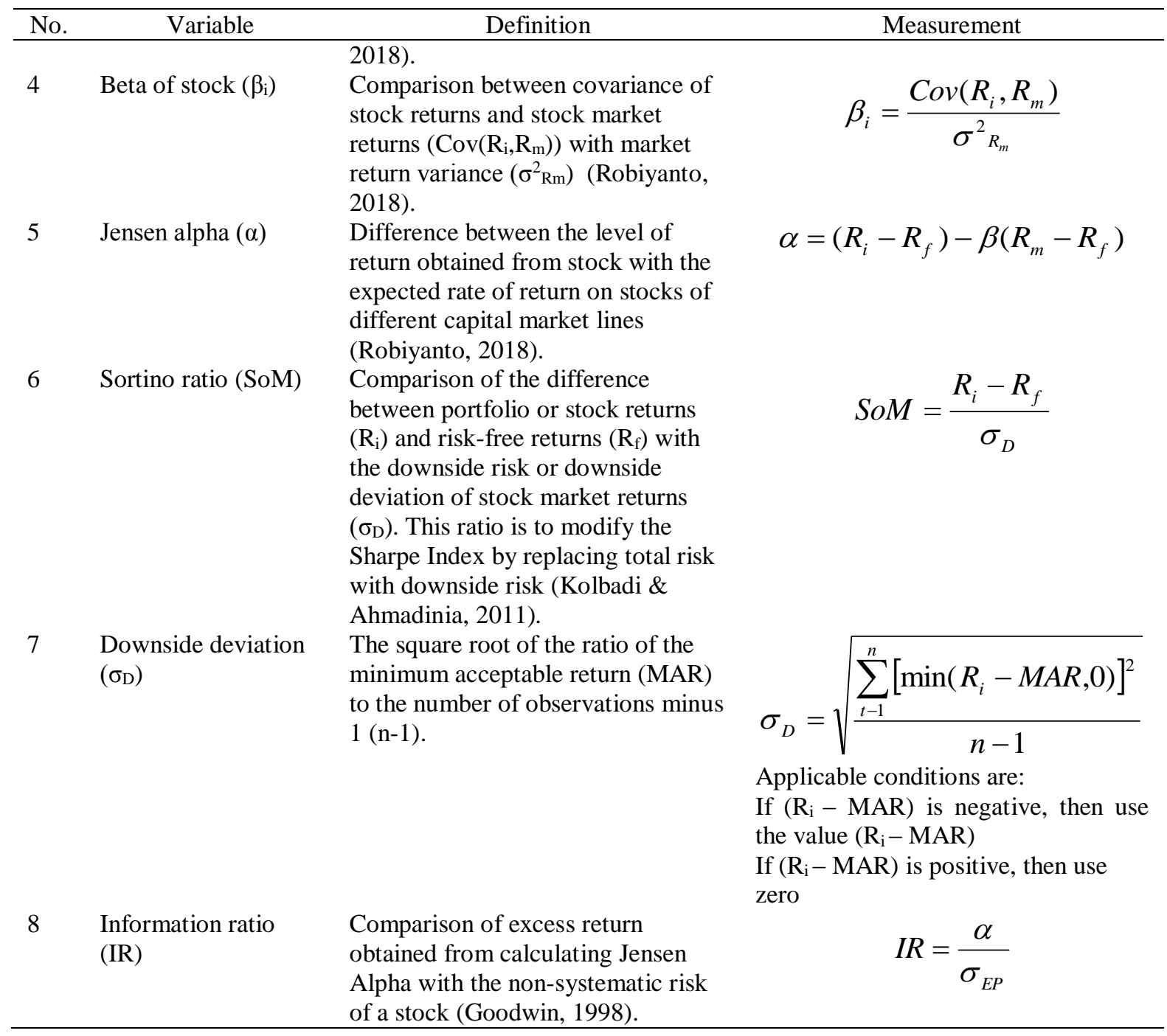

\section{DISCUSSION}

\section{LQ45 Index Stock Performance Using the Sharpe Index}

Measurement of stock performance using the Sharpe Index takes into account the standard deviation of returns for each stock. The standard deviation occurs from the return obtained by a stock compared to the average stock return. The closing price of a stock in a certain period to calculate the return and standard deviation of a stock, where the yield history used to predict the stock performance in the future period. If the results of the Sharpe Index calculation get bigger, then the stocks' performance is getting better. The lowest result on the Sharpe Index calculation for the period of 2016-2018 was SSMS stock in 2016, amounting to -0.6296 , while the highest yield was 0.9935 of ADRO stock in 2016. The highest average result in all periods was BBCA stock, amounted to 0.3432. From 2016 to 2018, not all Sharpe Index results showed a positive number. This means that not all stocks included in the LQ45 index show good performances because the results are not all positive. There were 13 stocks of underperformance, namely: ADHI, AKRA, BSDE, INTP, JSMR, LPKR, LPPF, MNCN, PGAS, PTPP, SCMA, SSMS, and WIKA where the average value was negative in all periods.

\section{LQ45 Index Stock Performance Using the Treynor Ratio}

Measuring a stock performance using the Treynor Ratio calculation uses the average of returns and betas for a certain period as a risk used as a benchmark for calculation. A fluctuating beta value indicates a change from the uncertain return of a stock to changes in the overall return of the market. 
The reason for using beta as a risk reference in investing is the uncertainty of stock prices is due to fluctuations in market prices. If the beta value is less than 1 , it means that the risk on the stock is smaller than market risk. Meanwhile, if the beta value is more than 1, the risk to the stock is greater than the market risk. The result of the Treynor Ratio that has a positive value means that stock performance is good, so the higher the value of the Treynor Ratio the better the stock performance. The stock that has the lowest value is SRIL in 2017 amounting to $-1,7003$, conversely the highest value of 0.0920 in SSMS stock in 2017. Based on the average results of all periods in the Treynor Ratio calculation, a stock that has the highest value is INCO with an average a result of 0.0333 . It can also be seen in the results of the Treynor Ratio calculation both in each year and average of all periods, not all calculation results show a positive value. This means that based on the Treynor Ratio calculation, not all stocks included in the LQ45 index have good performance. These stocks are ADHI, AKRA, BSDE, INTP, JSMR, LPKR, LPPF, MNCN, PGAS, PTBA, PTPP, SCMA, SSMS, and WIKA.

\section{LQ45 Stock Performance Using the Jensen Alpha}

Based on the Jensen Alpha method, stocks that have good performance stock with positive Jensen Alpha values. A negative Jensen Alpha value indicates poor stock conditions. This negative value ensures that the stock index is below the market index.

The results of the Jensen Alpha which has the smallest value during the 2016-2018 periods are PGAS stocks in 2017 with a value of -0.0504 . Besides that, the highest calculation result during the study period was held by PTBA stock in 2017 with a value of 0.5977 . The average overall calculation results are 18 stocks that have poor performance, namely: ADHI, AKRA, BSDE, INTP, JSMR, KLBF, LPKR, LPPF, MNCN, PGAS, PTPP, SCMA, SMGR, SRIL, SSMS, UNVR, WIKA, and WSKT. Whereas the stocks with the best performance are PTBA stock with a value of 0.1446 based on the average results of all periods.

\section{LQ45 Stock Performance Using the Sortino Ratio}

There is a similarity between the Sortino and Sharpe methods in measuring stock performance, the difference is in the involvement of downside risk in the Sortino method. Another difference is to include a risk-free rate in the Sharpe Ratio that proxies by the 7-days repo rate, then substituted by Minimum Acceptable Return (MAR) in the Sortino Ratio. The higher the value generated from Sortino Ratio calculation, means that the stock performance is getting better. While the lower the Sortino Ratio value indicates that stock performance is not good.

The lowest results from the Sortino Ratio calculation during the 2016-2018 periods were -0.9630 , namely in LPKR stock in 2018. Whereas the highest value was 8.5558 in BBNI stock in 2017. From the results of the Sortino Ratio calculation, it is known that not all stock performances are good, this indicated existence of stocks that have average negative calculation results. 13 stocks have poor performances, namely: ADHI, AKRA, BSDE, INTP, JSMR, LPKR, LPPF, MNCN, PGAS, PTPP, SCMA, SSMS, and WIKA. As for the stock that has the best performance is PTBA with an average value of 0.9924 according to the average calculation results from all periods.

\section{LQ45 Stock Performance Using the Information Ratio}

A stock has a good performance when the value of the information ratio shows a positive number. This positive value means that the return generated by a stock exceeds the risk-free return. And vice versa, it is said that the stock's performance is not good if it has a negative value.

The lowest value in the Information Ratio calculation is -0.7837 which is SSMS stock in 2016, while the highest value during the study periods is 0.8121 , which is ADRO stock in 2016. A stock that has an Information Ratio value above zero means that it has good performance or the stock's performance exceeds that of the benchmark. Meanwhile, a stock that has a value below zero means that the stock performance is below the benchmark performance or the stock has a poor

JMER, 2020, 01(1), 37-44 
performance. Based on the results of the Information Ratio calculation, not all stocks that are consistently included in the LQ45 index during the 2016-2018 periods have a good performance. 18 stocks have poor performances, namely: ADHI, AKRA, BSDE, INTP, JSMR, KLBF, LPKR, LPPF, MNCN, PGAS, PTPP, SCMA, SMGR, SRIL, SSMS, UNVR, WIKA, and WSKT. While the stock that has the best performance is BBCA with an average Information Ratio calculation of 0.2270 .

\section{CONCLUSION}

This study analyzes performance of 32 stocks that are consistently included in the LQ45 Index during the 2016-2018 periods. This research reviews these stock's performance according to five analytical methods. They are Sharpe Index, Treynor Ratio, Alpha Jensen, Sortino Ratio, and Information Ratio. The analysis revealed in the previous section, as a whole, it is concluded that not all stocks in this sample performed well. Based on performance evaluation using the Sharpe Index calculation method, 13 stocks have poor performances and the stock that has the best performance is BBCA. For evaluations using the Treynor Ratio, 14 stocks have not shown good performances. Whereas the stocks that showed the best performance during the research period using the Treynor Ratio were INCO stock. And based on the Jensen Alpha measurement method, 18 stocks have poor performances and the stock that has the best performance is PTBA stock.

Evaluation of the stock performance using the Sortino Ratio method shows that 13 stocks have calculation results below zero, which means that the results of their performances are still not good. Whereas the stock with the best performance using the Sortino Ratio is PTBA stock. For measuring the stock performance using Information Ratio, 18 stocks show poor performance, and for the stock with the best performance is BBCA stock. Of all methods of measuring stock performance, not all stocks included in the LQ45 index have good performances. From 32 stocks that included in the LQ45 index, 13 stocks always had a negative value in each method of measuring stock performance. These stocks are ADHI, AKRA, BSDE, INTP, JSMR, LPKR, LPPF, MNCN, PGAS, PTPP, SCMA, SSMS, WIKA.

This study still has limitations on the object of research, where the focus of this study is only on each stock included in the LQ45 index. It is expected that further research will not only evaluate the performance of each stock but contemplates an action a portfolio consisting of LQ45 stocks. Stocks that have underperformed in this study, not necessarily in the next period will have the same performances. Therefore, further research is expected to always use the latest period or update period, because stock performance is not always the same and is cyclical.

\section{REFERENCES}

Blatt, S. L. (2004). An In-Depth Look at the Information Ratio. Worcester Polytechnic Institute.

Chandra, L., \& Hapsari, Y. D. (2013). Analisis Pembentukan Portofolio Optimal dengan Menggunakan Model Markowitz untuk Saham LQ 45 Periode 2008-2012. Jurnal Manajemen, l(1), 41-65.

Devaki, A. (2017). Faktor-Faktor yang Mempengaruhi Return Saham pada Perusahaan LQ45 di Bursa Efek Indonesia. Jurnal Benefita, 2(2), 157-168. https://doi.org/10.22216/jbe.v2i2.2004

Flotyński, M. J. (2015). The Efficiency Of Stock Market Indices in Poland-The Empirical Evidence. Prace Naukowe Uniwersytetu Ekonomicznego We Wrocławiu, 386, 27-50.

Goodwin, T. H. (1998). The Information Ratio. Financial Analysts Journal, 54(4), 34-43. https://doi.org/https://doi.org/10.2469/faj.v54.n4.2196

Hsieh, H., \& Hodnett, K. (2013). A Review of Performance Evaluation Measures for ActivelyManaged Portfolios. Journal of Economics and Behavioral Studies, 5(12), 815-824.

Indonesia Stock Exchange (IDX). (2018). Stock List for LQ45 Index Calculation. Retrieved from www.idx.co.id

Jensen, M. C. (1967). The Performance of Mutual Funds in the Period 1945-1964. Journal of Finance, 23(2), 389-416. https://doi.org/10.2139/ssrn.244153

Kidd, D. (2011). The Sharpe Ratio and The Information Ratio. Investment Performance Measurement

JMER, 2020, 01(1), 37-44 
Feature Articles, (1), 1-4.

Kolbadi, P., \& Ahmadinia, H. (2011). Examining Sharp, Sortino and Sterling Ratios in Portfolio Management , Evidence from Tehran Stock Exchange. 6(4), 222-236. https://doi.org/10.5539/ijbm.v6n4p222

Lakaba, A., \& Robiyanto. (2018). Evaluasi Kinerja Saham Bertanggungjawab Sosial (Studi pada Saham-saham yang Masuk Perhitungan Indeks Sri-Kehati). Jurnal Organisasi Dan Manajemen, 14(2), 94-106.

Larasati, D., Irwanto, A. K., \& Permanasari, Y. (2013). Analisis Strategi Optimalisasi Portofolio Saham LQ 45 (pada Bursa Efek Indonesia Tahun 2009-2011). Jurnal Manajemen Dan Organisasi, 4(2), 163-171. https://doi.org/https://doi.org/10.29244/jmo.v4i2.12623

Leković, M. (2017). Mutual Funds Portfolio Performance Evaluation Models: Sharpe, Treynor and Jensen Index. Bankarstvo, 46(4), 108-133.

Markowitz, H. M. (1959). Portfolio Selection: Efficient Diversification of Investments. New York: John Wiley \& Sons, Inc.

Nurhayati, A., Suryantini, A., \& Jamhari, J. (2017). Performance Evaluation and Optimum Portfolio Allocation for Stocks of Agribusiness and Non-Agribusiness Companies in ILQ45. Ilmu Pertanian (Agricultural Science), 1(3), 115-122. https://doi.org/10.22146/ipas.9240

Pangestuti, I. R. D., Wahyudi, S., \& Robiyanto. (2017). Performance Evaluation of Equity Based Mutual Funds in India. Jurnal Keuangan Dan Perbankan, 21(4), 527-542. https://doi.org/https://doi.org/10.26905/jkdp.v21i4.1503

Putra, M. P. S., Atahau, A. D. R., \& Robiyanto. (2018). Cross - asset Class Portfolio between Qold and Stocks in Indonesia. Economic Journal of Emerging Markets, 10(1), 69-81. https://doi.org/10.20885/ejem.vol10.iss1.art8

Robiyanto, R. (2018). Performance Evaluation of Stock Price Indexes in the Indonesia Stock Exchange. International Research Journal of Business Studies, 10(3), 173-182. https://doi.org/https://doi.org/10.21632/irjbs

Rollinger, T. N., \& Hoffman, S. T. (2013). Sortino : A 'Sharper ' Ratio. Illinois: Red Rock Capital.

Sharpe, W. F. (1966). Mutual Fund Performance. Journal of Business, 39(1), 119-138. https://doi.org/http://dx.doi.org/10.1086/294846

Sortino, F. A., \& Price, L. N. (1994). Performance Measurement in A Downside Risk Framework. THE JOURNAL OF INVESTING, 3(3), 59-64. https://doi.org/https://doi.org/10.3905/joi.3.3.59

Suryani, A., \& Herianti, E. (2015). The Analysis of Risk Adjusted Return Portfolio Performance Share for LQ 45 Index in Indonesia Stock Exchange in 2010-2014 Periods. Procedia - Social and Behavioral Sciences, 211, 634-643. https://doi.org/10.1016/j.sbspro.2015.11.087

Treynor, J. L. (1965). How to Rate Management of Investment Funds. Harvard Business Review, $43(1), 63-75$.

Wahyuningrum, D. (2010). Pemilihan dan Pembentukan Portofolio Saham LQ45 yang Optimal (Studi Kasus di Bursa Efek Indonesia (BEI)). Journal of Indonesian Applied Economics, 4(1), 26-33.

Zakarias, V. A., \& Tumewu, F. (2015). Evaluating Portfolio Performance Of Companies'stock Listed in LQ45 Based On Sharpe, Treynor and Jensen Method. Jurnal EMBA, 3(2), 55-64.

Zulkafli, A. H., Ahmad, Z., \& Eky Ermal, M. (2017). The Performance of Socially Responsible Investments in Indonesia: A Study of the Sri Kehati Index (SKI). Gadjah Mada International Journal of Business, 19(1), 59-76. https://doi.org/10.22146/gamaijb.17959 